\title{
PENGAJARAN SEJARAH DI PENDIDIKAN SEJARAH \\ PADA ERA REVOLUSI INDUSTRI 4.0
}

\author{
Hamid Hasan \\ Email : eshamidhasan@gmail.com \\ $\underline{\text { (Guru Besar Jurusan Sejarah Universitas Pendidikan Indonesia) }}$
}

\section{PEMBELAJARAN SEJARAH \\ DI PENDIDIKAN SEJARAH PADA ERA REVOLUSI INDUSTRI 4.0}

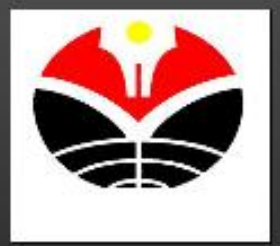

S. HAMID HASAN UNIVERSITAS PENDIDIKAN INDONESIA

SEMINAR NASIONAL

PERKUMPULAN PRODI PENDIDIKAN SEIARAH PADANG, UNP: 23 APRIL 2019

\section{PARADIGMA BARU PROGRAM SARJANA PENDIDIKAN SEJARAH}

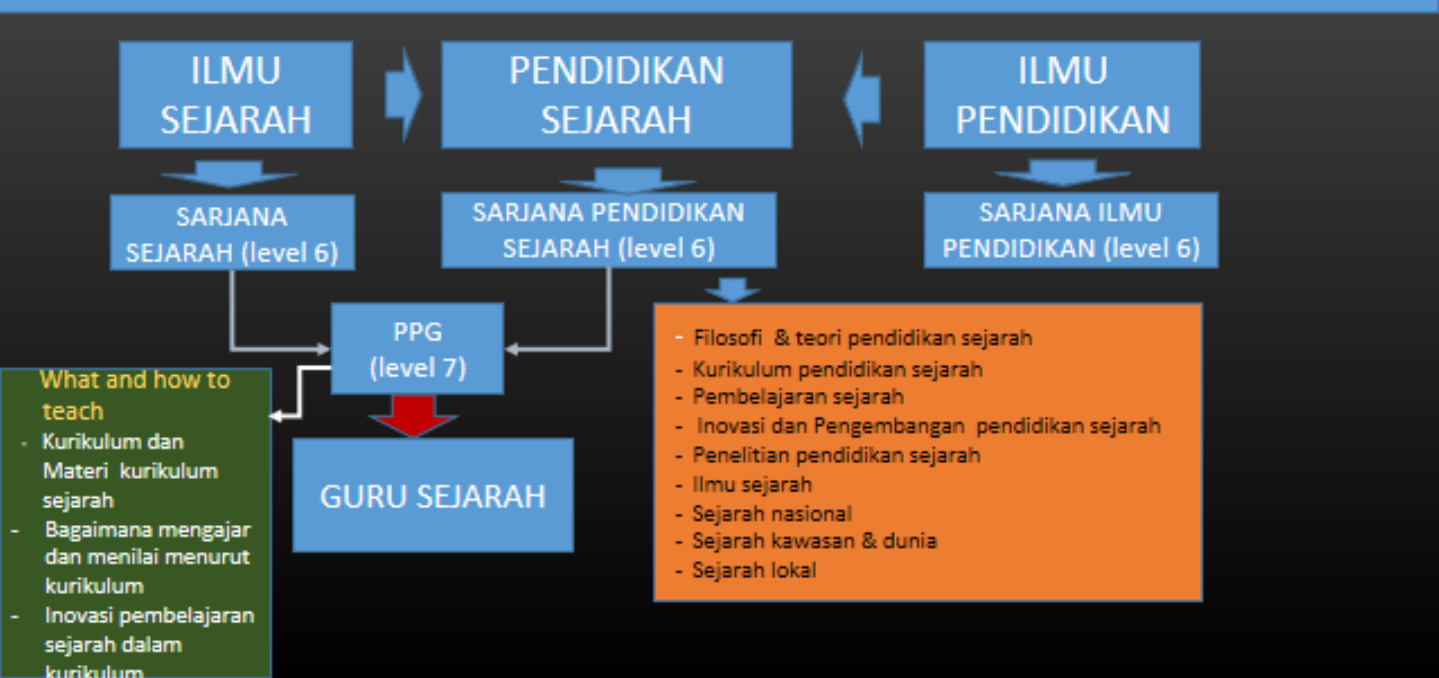

21 | Seminar Nasional Sejarah ke 4 Jurusan Pendidikan Sejarah Universitas Negeri Padang 
KOMPETENSI DAN KAJIN SARJANA PENDIDIKAN SEJARAH S-1, S-2, S-3

\section{*SARJANA PADA LEVEL 6 (S-1), 8 (S-2), DAN 9 (S-3) KKNI}

* MEMILIKI KOMPETENSI DALAM MENGGUNAKAN ILMU PENDIDIKAN TERUTAMA TEORI KURIKULUM, PEMBELAJARAN/TEACHING, DAN PENILAIAN HASIL BELAJAR DALAM MENGKAII DAN MENGEMBANGKAN PENDIDIKAN SEJARAH DI JENJANG PENDIDIKAN DASAR, MENENGAH, DAN TINGGI SECARA FILOSOFIS, TEORITIK, DAN KENYATAAN EMPIRIK

\& PENDIDIKAN SEJARAH YANG DIKAII BERKENAAN DENGAN ASPEK FILOSOFI, RANCANGAN PENDIDIKAN, PROSES PEMBELAJARAN, HASIL BELAJAR, GURU/DOSEN, PESERTA DIDIK, MASYARAKAT, PERKEMBANGAN KEHIDUPAN BANGSA, DAN KEBIJAKAN PENDIDIKAN DI BIDANG PENDIDIKAN SEJARAH, DI JENJANG PENDIDIKAN DASAR - PENDIDIKAN TINGGI DAN DI BERBAGAI JALUR PENDIDIKAN

\section{KOMPETENSI UTAMA SARJANA PENDIDIKAN SEJARAH}

\section{S3}

\section{S2}

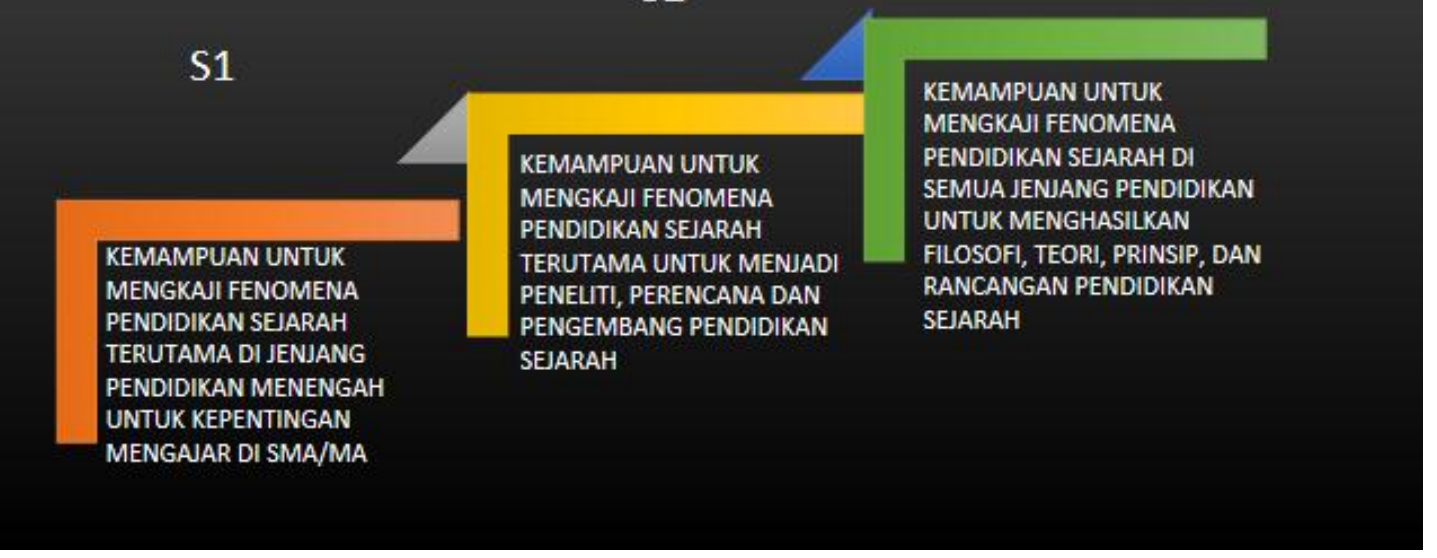

22 | Seminar Nasional Sejarah ke 4 Jurusan Pendidikan Sejarah Universitas Negeri Padang 


\section{KOMPETENSI TAMATAN PENDIDIKAN SEJARAH}

S-

3

PENGEMBANG ILMU DAN PROGRAM PENDIDIKAN SEJARAH (DOSEN)

S-1

-1 PENGEMBANG PEMBELAJARAN PENDIDIKAN SEJARAH (GURU)

PENELITI DAN PERENCANA PROGRAM PENDIDIKAN SEJARAH (DOSEN)

S-2 


\section{BIDANG KAJIAN SARJANA PENDIDIKAN SEJARAH}

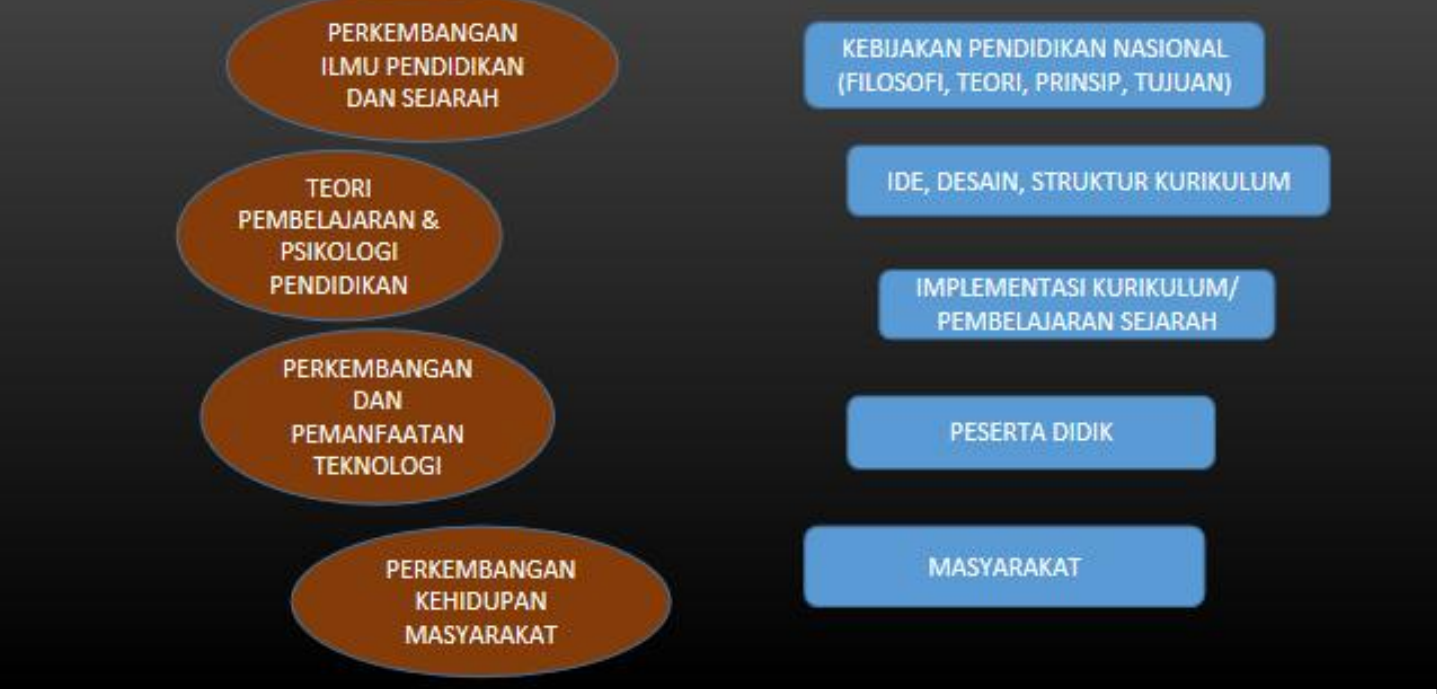

KETRAMPILAN UMUM LULUSAN PROGRAM SARJANA

- mampu menerapkan pemikiran logis, kritis, sistematis, dan inovatif dalam konteks pengembangan atau implem entasi ilmu pengetahuan dan teknologi yang memperhatikan dan menerapkan nilai humanio ra yang sesuai dengan bidang ke ahliannya;

- Mampu menunjukkan kinerja mandiri, bermutu, dan terukur

- mampu mengkaji implikasi pengembangan atau implementasi ilmu pengetahuan dan teknologi yang memperhatikan dan menerapkan nilai humaniora sesuai dengan ke ahliannya berdasarkan kaidah, tata cara dan etika ilmiah dalam rangka menghasilkan solusi, gagasan, desain atau kritik seni;

- Mampu menyusun de skripsi saintifik hasil kajian tersebut di atas dalam bentuk skripsi atau laporan tugas akhir, dan mengunggahnya dalam laman perguruan tinggi;

- mampu mengambil keputusan secara tepat dalam konteks penyelesaian masalah di bidang keahliannya, berdasarkan hasil analisis informasi dan data;

- mampu memelihara dan mengemban gkan jaringan kerja dengan pembimbing, kolega, sejawat baik di dalam maupun di luar lembaganya.

- mampu bertanggung jawab atas pencapaian hasil kerja kelompok dan melakukan supervisi serta evaluasi terhadap penyelesaian pekerjaan yang ditugaskan kepada pekerja yang berada di bawah tanggung jawabnya;

- mampu melakukan proses evaluasi diri terhadap kelompok kerja yang berada di bawah tanggung jawabnya, dan mampu mengelola pembelajaran secara mandiri.

- mampu mendokumentasikan, menyimpan, mengamankan, dan menemukan kembali data untukmenjamin kesahihan dan mencegah plagiasi; 


\section{KETRAMPILAN UMUM LULUSAN PROGRAM MAGISTER}

- mampu mengembangkan pemikiran logis, kritis, sistematis, dan kreatif melalui penelitian ilmiah, penciptaan desain ata u karya seni dalam bidang ilmu pengetahuan dan teknologi yang memperhatikan dan menerapkan kaidah, tata cara, dan etika ilmiah dalam bentuk tesis yang dipublikasikan tulisan dalam jumal ilmiah yang terakreditasi:

- mampu melakukan validasi akademik atau kajian sesuai bidang keahliannya dalam menyelesaikan masalah di masyarakat atau industri yang relevan melalui pengembangan pengetahuan dan keahliannya;

- mampu menyusun ide, hasil pemikiran dan argumen saintifik secara bertanggung jawab dan berdasarkan etika akademik, serta menkomunikasikan melalui media kepada masyarakat akademik dan masyarakat luas:

- mampu mengidentifikasi bidang keilmuan yang menjadi obyek penelitianmya dan memosisikan ke dalam suatu peta penelitian yang dikembangkan melalui pendekatan inter atau multi disipliner;

- mengambil keputusan dalam konteks menyelesaikan masalah pengembangan ilmu pengetahuan dan teknologi yang memperhatikan dan menerapkan nilai humaniora berdasarkan kajian, analisis atau eksperimental terhadap informasi dan data;

- mampu mengelola, mengembangkan dan memelihara jaringan kerja dengan kolega, sejawat di dalam lembaga dan komunitas penelitian yang lebih luas;

- mampu meningkatkan kapasitas pembelajaran secara mandiri;

- mampu mendokumentasikan, menyimpan, mengamankan, dan menemukan kembali data hasil penelitian dalam rangka menjamin kesahihan dan mencegah plagiasi.

\section{KETRAMPILAN UMUM LULUSAN PROGRAM DOKTOR}

- mampu menemukan aau mengembangkan teori/konsepsi/gagasan ilmiah, dan memberikan kontribusi pada pengembangan, serta pengamalan ilmu pengeahuan dan/atau teknologi yang memperhailkan dan menerapkan nilai humaniora di bidang keahliannya dengan menghasilkan penelitian ilmiah berdasarkan metodolog ilmiah, pemiluran logis, iritis, stemats, dan kreatif;

- mampu menyusun penelitian interdisplin, multidisiplin atau transdisiplin,termasuk kajian teoritis dan/atau eksperimen pada bidang keilmuan, telnolog, seni, dan inovasi yang dihasilkannya dalam bentuk desertas, seta mempublikasikan 2 tulisan pada jurnal ilmiah internasional ter indels.

- mampu memilih penelitian yang tepat guna terkini dan termaju dan memberikan kemaslahatan pada uma manusia melalui pendekatan interdisplin, multidisplin, ata. transdispliner, dalam rangkamengembangkan dan/aau menghasilkan penvelesaian masala di bidang keilmuan, teknologi, seni, atau kemas/arakatan, berdasarkan hasil kajian tentang ketersediaan sumberda/a internal maupun elsternal

- mampu mengembangkan peta jäan penelitian dengan pendekatan interdisiplin, multidisiplin, atau transdisipliner, berdasarkan kajian tentang sasaran pokok penelitian seta kontelasinya pada sasaran yang lebih luas

- mampu menyusun agumen dan solusi keilmuan, teknologi atau seni berdasarkan pandangan kritis atas falta, konsep, prinsip, àu teori yang dapa dipertanggungianabkan secara ilmiah dan etika akademik, serta menglomunikaskanny a melaui media masa atau langyng kepada masy arakat

- mampu menunjukkan kepemimpinan akademik dalam pengelolaan, pengembangan dan pembinaan sumberda/a serta organisas yang berada dibanah tanggung jawabnya

- mampu mengelola, termasuk menyimpan, mengaudit, mengamankan, dan menemukan kembali data dan informasi hasilpenelitian yang berada dibawah tanggung jasabnya

- mampu mengembangkan dan memelihara hubungan kolegial dan kesejawatan didalam lingungan sendiri atau melaluijaringan kerja sama dengan komunitas peneliti diluar lemb aga 


\section{PEMBELAJARAN PROGRAM PENDIDIKAN SEJARAH DI ERA REVOLUSI INDUSTRI 4.0}

TUJUAN PEMBELAJARAN YANG HAKIKI ADALAH MENGEMBANGKAN POTENSI PESERTA DIDIK/MAHASISWA MENJADI KEMAMPUAN UNTUK BELAJAR SEPANJANG HAYAT (LIFELONG LEARNING; LIFETIME LEARNING) 


\section{LIFELONG LEARNING C)> LIFETIME LEARNING}

- LIFETIME LEARNING ADALAH KEMAMPUAN UNTUK BELAJAR FROM CRADLE TO GRAVE (MINAL MAHDI ILAL LAHDI)

- KEMAMPUAN BELAJAR ADALAH KOMPETENSI YANG BERSIFAT DEVELOPMENTAL, DIPERKAYA DAN DIPERBAIKI SEPANJANG HAYAT.

- PEMBELAJARAN DI LEMBAGA PENDIDIKAN MENGEMBANGKAN KUALITAS PEMBELAJAR SEUMUR HIDUP

\section{PENGERTIAN BELAJAR}

AKTIF

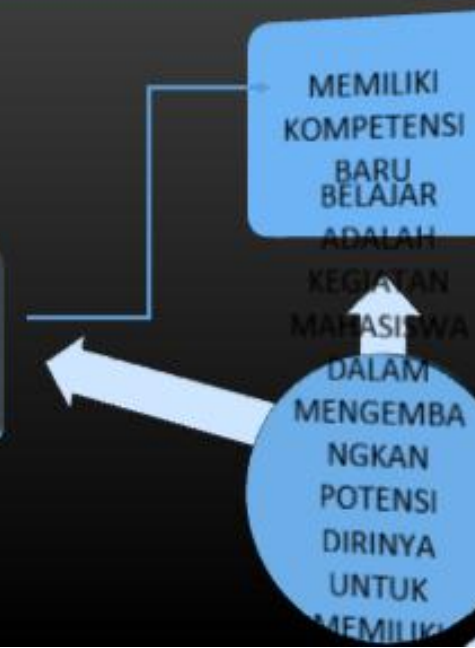

MENJADI

SEORANG YANC

BARU 


\section{PRINSIP PEMBELAJARAN}

PEMBELAJARAN SELALU HARUS MEMBERIKAN KEPEDULIAN KEPADA PENGEMBANGAN POTENSI MAHASISWA UNTUK MEMILIKI KOMPETENSI BAGI KEHIDUPAN DIRINYA SEBAGAI INDIVIDU, ANGGOTA MASYARAKAT, WARGANEGARA, ILMUWAN DAN WARGA PROFESI, SERTA UMMAT MANUSIA.

- PEMBELAIARAN MENGEMBANGKAN KEMAMPUAN MAHASISWA UNTUK MEMANFATKAN TEKNOLOGI BAGI KEBAHAGIAAN HIDUP SEBAGAI INSAN

- PEMBELAJARAN SELALU MEMANFAATKAN TEKNOLOGI YANG BERKEMBANG DAN DIGUNAKAN MASYARAKAT.

- TEKNOLOGI ADALAH BAGIAN DARI METODE DAN PENDEKATAN PEMBELAJARAN YANG DIGUNAKAN UNTUK MENINGKATKAN NILAI DAN KEMAMPUAN KEMANUSIAAN MAHASISWA DALAM PENGETAHUAN, KOGNITIF, AFEKTIF, DAN KETRAMPILAN PSIKOMOTOR/KINESTETIK

- PENGGUNAAN TEKNOLOGI BERPENGARUH TERHADAP HASIL BELAIAR, KONTEN, PROSES PEMBELAJARAN, DAN PENILAIAN HASIL BELAJAR

\section{PRINSIP PEMBELAJARAN}

PEMBELAJARAN SELALU HARUS MEMBERIKAN KEPEDULIAN KEPADA PENGEMBANGAN POTENSI MAHASISWA UNTUK MEMILIKI KOMPETENSI BAGI KEHIDUPAN DIRINYA SEBAGAI INDIVIDU, ANGGOTA MASYARAKAT, WARGANEGARA, ILMUWAN DAN WARGA PROFESI, SERTA UMMAT MANUSIA.

- PEMBELAJARAN MENGEMBANGKAN KEMAMPUAN MAHASISWA UNTUK MEMANFATKAN TEKNOLOGI BAGI KEBAHAGIAAN HIDUP SEBAGAI INSAN

- PEMBELAJARAN SELALU MEMANFAATKAN TEKNOLOGI YANG BERKEMBANG DAN DIGUNAKAN MASYARAKAT.

- TEKNOLOGI ADALAH BAGIAN DARI METODE DAN PENDEKATAN PEMBELAJARAN YANG DIGUNAKAN UNTUK MENINGKATKAN NILAI DAN KEMAMPUAN KEMANUSIAAN MAHASISWA DALAM PENGETAHUAN, KOGNITIF, AFEKTIF, DAN KETRAMPILAN PSIKOMOTOR/KINESTETIK

- PENGGUNAAN TEKNOLOGI BERPENGARUH TERHADAP HASIL BELAJAR, KONTEN, PROSES PEMBELAJARAN, DAN PENILAIAN HASIL BELAJAR 


\section{PRINSIP BELAJAR}

- MAHASISWA AKTIF MENDAPATKAN PENGETAHUAN MELALUI BERBAGAI CARA BELAJAR SEPERTI MEMBACA, MENDENGAR DAN MENGAMATI

- MAHASISWA MAMPU MENGENAL BERBAGAI SUMBER BELAJAR (SUMBER TERTULIS, MEDIA ELEKTRONIK, INTERNET OF THINGS (IoT)

- MAHASISWA MAMPU MENGUMPULKAN DAN MENGOLAH INFORMASI YANG DIPEROLEH DENGAN MENERAPKAN KEMAMPUAN BERPIKIR

- MAHASISWA MAMPU MENGGUNAKAN PENGETAHUAN DAN KETRAMPILAN BERPIKIR UNTUK BERBAGAI MASALAH YANG DIHADAPI

KUALITAS HASIL BELAJAR MAHASISWA PENDIDIKAN SEJARAH

- MEMILIKI PENGETAHUAN MENGENAI PENDIDIKAN INDONESIA, ILMU SEJARAH, PENDIDIKAN SEJARAH

- MAHASISWA MEMILIKI KEINGINANTAHU (CURIOSITY)

- MEMILIKI KEMAMPUAN BELAJAR (MENENTUKAN SUMBER, MENCARI INFORMASI, MENGOLAH INFORMASI, MENYIMPULKAN)

- MEMILIKI KEBIASAAN BELAJAR

- KEMAMPUAN MENGGUNAKAN PENGETAHUAN, KETRAMPILAN BERPIKIR, KETRAMPILAN KINESTETIK/PSIKOMOTOR UNTÚK PENGEMBANGAN ILMÚ DAN PROFESI

- KEMAMPUAN BERTINDAK PROFESIONAL BERDASARKAN KAEDAH ILMU DAN PROFESI (MANAGEMENT OF FEELINGS)

- MAMPU MENGEMBANGKAN KERJASAMA DAN BERKOMUNIKASI 


\section{Navigating the next industrial revolution}

\begin{tabular}{llll} 
Revolution & Year & Information \\
\hline 2 & 1870 & 1784 & Steam, water, mechanical production equipment \\
& 3 & 1969 & Electronics, IT, automated production \\
& & & \\
4 & $?$ & Cyber-physical systems
\end{tabular}

Keidanren

Policy \& Action

KEHIDUPAN MANUSIA DAN PERKEMBANGAN

TEKNOLOGI
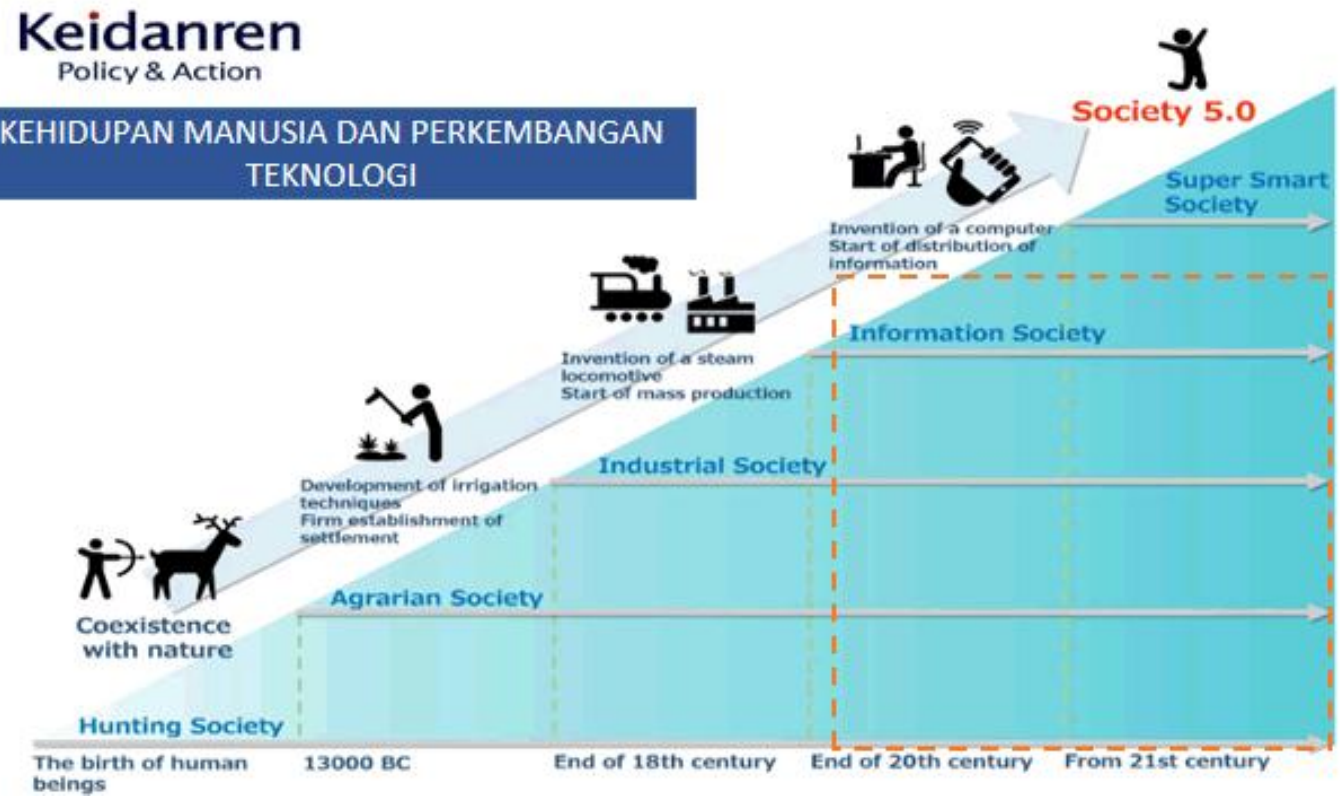

30 | Seminar Nasional Sejarah ke 4 Jurusan Pendidikan Sejarah Universitas Negeri Padang 


\section{PENGERTIAN REVOLUSI INDUSTRI 4.0}

- IT IS CHARACTERIZED BY A FUSION OF TECHNOLOGIES THAT IS BLURRING THE LINES BETWEEN THE PHYSICAL, DIGITAL, AND BIOLOGICAL SPHERES,

COLLECTIVELY REFERRED TO AS

- IT IS MARKED BY EMERGING TECHNOLOGY BREAKTHROUGHS IN A NUMBER OF FIELDS, INCLUDING ROBOTICS, ARTIFICIAL INTELLIGENCE, NANOTECHNOLOGY, QUANTUM COMPUTING, BIOTECHNOLOGY, THE INTERNET OF THINGS, THE INDUSTRIAL INTERNET OF THINGS (IIOT), BLOCKCHAIN, FIFTH-GENERATION WIRELESS TECHNOLOGIES (5G), ADDITIVE MANUFACTURING/3D PRINTING AND FULLY AUTONOMOUS VEHICLES.

\section{WIKIPEDIA 2019}
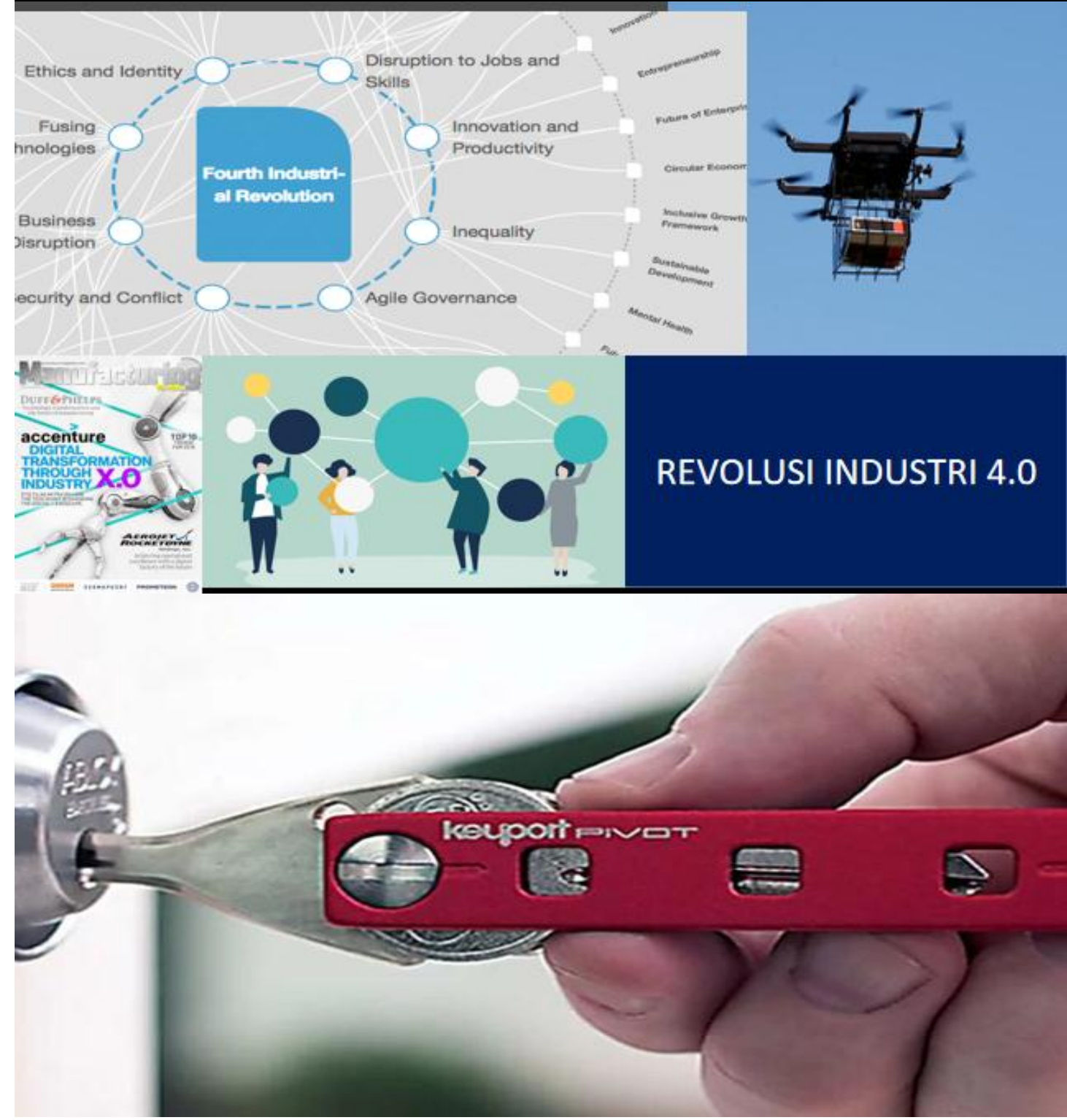

31 | Seminar Nasional Sejarah ke 4 Jurusan Pendidikan Sejarah Universitas Negeri Padang 


\section{KEHIDUPAN ABAD KE 21}

- KEHIDUPAN ABAD KE 21 DIWARNAI OLEH PERUBAHAN-PERUBAHAN YANG DIPENGARUHI OLEH REVOLUSI GLOBALISASI, TEKNOLOGI KOMUNIKASI YANG MENJADI DASAR BAGI REVOLUSI INDUSTRI 4.0, DAN DUNIA BISNIS YANG DIKENAL DENGAN ISTILAH DISRUPTIVE ERA

- IT IS COMMONLY STATED THAT THE 21TH CENTURY SKILLS ARE CREATIVE, CRITICAL, COLLABORATIVE, COMMUNICATIVE, INTERNAL SELFMANAGEMENT, AND PROBLEM SOLVING

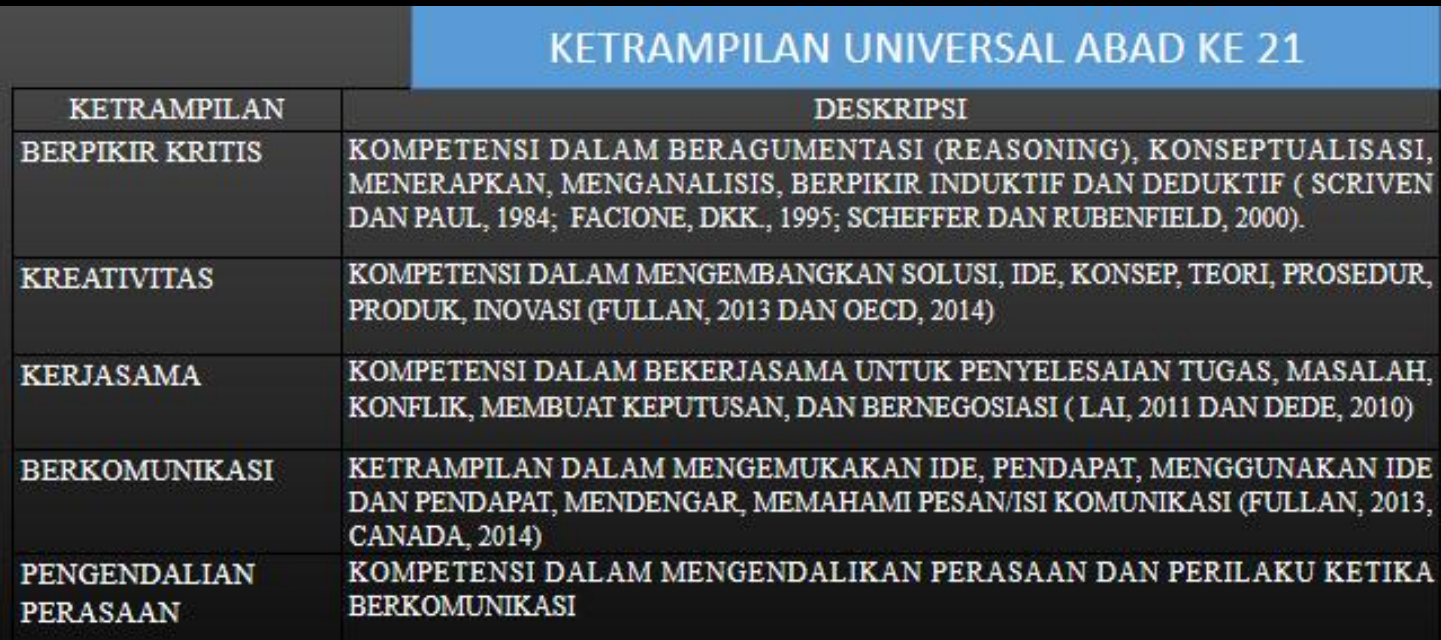

P E M E C A H A N KOMPETENSI DALAM PENYELESAIANMASALAH MASALAH 


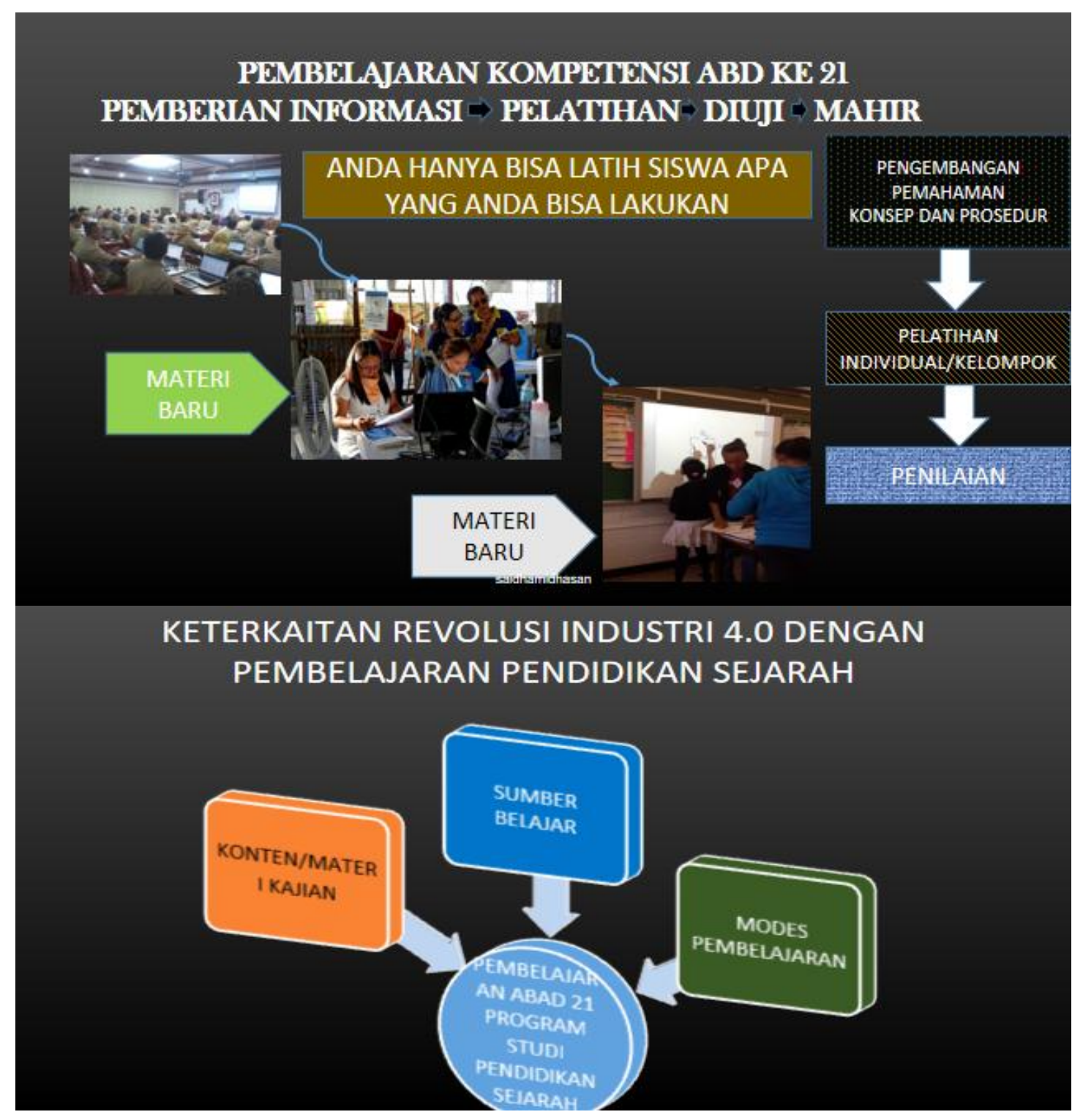

33 | Seminar Nasional Sejarah ke 4 Jurusan Pendidikan Sejarah Universitas Negeri Padang 


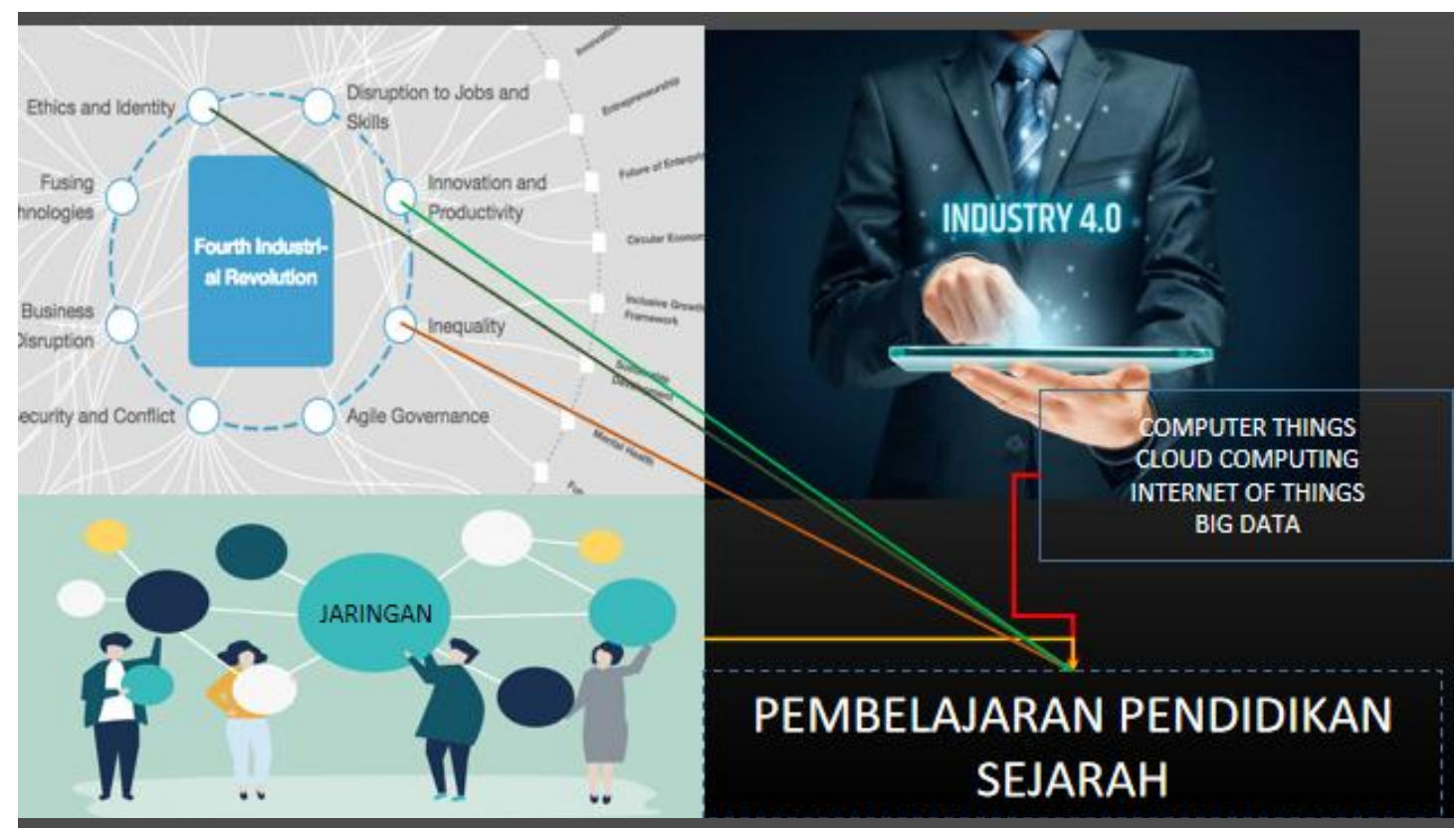

KETERKAITAN REVOLUSI INDUSTRI 4.0 DENGAN PENDIDIKAN SEJARAH

ASPEK KETERKAITAN

KONTEN/MATERI KAIIAN

SUMBER BELAJAR

MODES PEMBELAJARAN
DESKRIPSI

BAHAN KAIIAN BAGI MAHASISWA TENTANG:

- SEJARAH REVOLUSI INDUSTRI

- MANUSIA DAN REVOLUSI TEKNOLOGI

- PERUBAHAN DAN ADAPTASI KEHIDUPAN MANUSIA

- TEKNOLOGI DALAM PROSES PEMBELAJARAN

SUMBER UNTUK MATERI DAN PERLUASAN MATERI PERKULIAHAN: - INTERNET : WEB

PEMBELAJARAN DENGAN MODES:

- TATAP MUKA DENGAN PPT, VIDEO, ON-LINE CONTENT

- ON-LINE LEARNING

- OFF-LINE LEARNING (INDIVIDUL, KELOMPOK, PERSONALIZED)

- BLENDED 


\section{MODES PEMBELAJARAN DENGAN TEKNOLOGI REVOLUSI 4.0}

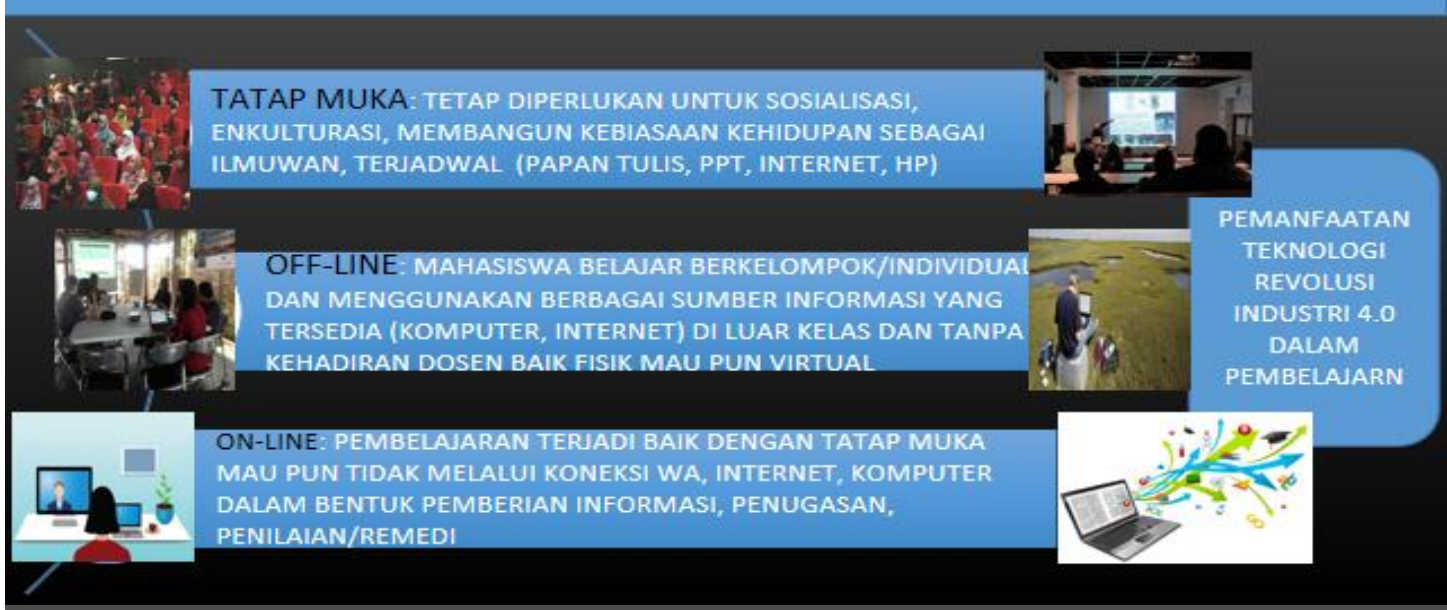

PEMBELAJARAN SEPANJANG HAYAT MELALUI PENGALAMAN PEMBELAJARAN SAINTIFIK 


\section{LANDASAN TEORITIK PENGALAMAN BELAJAR SAINTIFIK}

DNA INNOVATORS (DRYER, GREGERSEN, DAN CHRISTENSEN, 2011)

* 21TH CENTURY SKILLS (TRILLING AND FADEL, 2009)

* COMPETENCY-BASED CURRIUCLUM

* SOCIAL RECONSTRUCTIONISM

* MASTERY LEARNING

\section{PENGALAMAN BELAJAR SAINTIFIK}

\begin{tabular}{|c|c|c|}
\hline PENGALAMAN BELAIAR & $\begin{array}{l}\text { KUALTTAS BELAJAR YANG } \\
\text { DIKEMBANGKAN }\end{array}$ & $\begin{array}{l}\text { KETRAMPILAN BELAIAR YANG } \\
\text { DIKEMBANGKAN }\end{array}$ \\
\hline MENGAMATI & $\begin{array}{l}\text { RASA INGIN TAHU \& KEBIASAAN } \\
\text { BELAJAR }\end{array}$ & $\begin{array}{l}\text { KEHIDUPAN BERHADAPAN DENGAN } \\
\text { PERUBAHAN }\end{array}$ \\
\hline MENANYA & $\begin{array}{l}\text { RASA INGIN TAHU \& KEBIASAAN } \\
\text { BELAJAR }\end{array}$ & HIGHLY RELEVANT AND APPLICABLE \\
\hline MENGUMPULKAN INFORMASI & $\begin{array}{l}\text { KETRAMPILAN \& KEBIASAAN } \\
\text { BELAJAR }\end{array}$ & HIGHLY RELEVANT AND APPLICABLE \\
\hline MENGOLAH INFORMASI & $\begin{array}{l}\text { KETRAMPILAN DAN KEBIASAAN } \\
\text { BELAJAR }\end{array}$ & HIGHLY RELEVANT AND APPLICABLE \\
\hline MENGOMUNIKASI & $\begin{array}{l}\text { PERLUASAN OBSERVASI, } \\
\text { PERLUASAAN INFORMASI, } \\
\text { KOMUNIKASI SOSIAL, KEMAMPUAN } \\
\text { MENGEMUKAKAN IDE DAN } \\
\text { ARGUMENTASI }\end{array}$ & HIGHLY RELEVANT AND APPLICABLE \\
\hline
\end{tabular}

36 | Seminar Nasional Sejarah ke 4 Jurusan Pendidikan Sejarah Universitas Negeri Padang 


\section{KKNI}

\section{BEBERAPA KETENTUAN UMUM KKNI}

- Kerangka Kualifikasi Nasional Indonesia, yang selanjutnya disingkat KKNI, adalah kerangka penjenjangan kualifikasi kompetensi yang dapat menyandingkan, menyetarakan, dan mengintegrasikan antara bidang pendidikan dan bidang pelatihan kerja serta pengalaman kerja dalam rangka pemberian pengakuan kompetensi kerja sesuai dengan struktur pekerjaan di berbagai sektor

- Capaian pembelajaran adalah kemampuan yang diperoleh melalui internalisasi pengetahuan, sikap, ketrampilan, kompetensi, dan akumulasi pengalaman kerja 


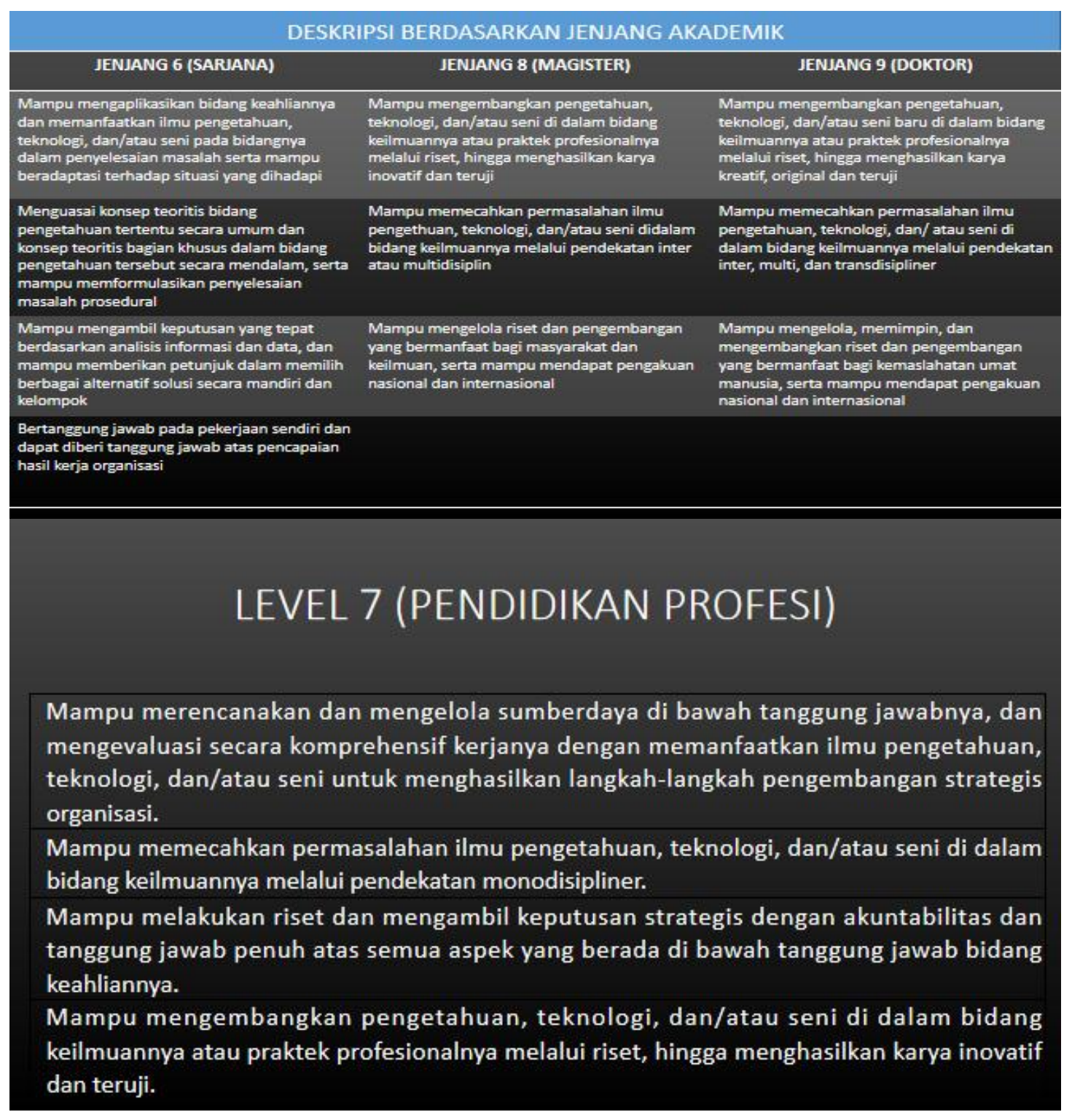

38 | Seminar Nasional Sejarah ke 4 Jurusan Pendidikan Sejarah Universitas Negeri Padang 


\section{STANDAR NASIONAL PENDIDIKAN TINGGI (PERMENDIKBUD NOMOR 49 TAHUN 2014)}

\section{CAPAIAN PEMBELAJARAN (CP)}

\section{PENGERTIAN CP}

- kemampuan yang diperoleh melalui internalisasi pengetahuan, sikap, keterampilan, kompetensi, dan akumulasi pengalaman kerja.

- merupakan penera (alat ukur) dari apa yang diperoleh seseorang dalam menyelesaikan proses belajar baik terstruktur maupun tidak.

- Rumusan CP disusun dalam 4 unsur yaitu sikap dan tata nilai, kemampuan kerja, penguasaan pengetahuan, dan wewenang dan tanggung jawab.

\section{KRITERIA CP}

- Kelengkapan unsur deskripsi.

- Kesesuaian dengan jenjang kualifikasi: - gradasi keterampilan khusus - gradasi penguasaan pengetahuan;

- Kejelasan batas bidang keilmuan/keahlian program studi;

- Tingkat penguasaan, kedalaman, dan keluasan bahan kajian yang harus dikuasaí;

- Referensi program studi sejenis sebagai pembanding;

- Kejelasan rumusan, adanya kesamaan arti bila dibaca awam/pemangku kepentingan. 


\section{CAPAIAN PEMBELAJARAN}

PENYUSUNAN CP DAPAT DILIHAT DALAM DUA KONTEKS, YAKNI PERTAMA BAGI PROGRAM STUDI BARU YANG AKAN DIUSULKAN ATAU PROGRAM STUDI YANG BELUM MENYATAKAN "KEMAMPUAN LULUSANNYA" SECARA FAKTUAL DAN TEPAT. DALAM KONTEKS INI PENYUSUNAN CP MERUPAKAN PROSES AWAL DARI PENYUSUNAN KURIKULUM PROGRAM STUDI. KEDUA, BAGI PROGRAM STUDI YANG SUDAH ADA ATAU SUDAH BEROPERASI. DALAM KONTEKS INI, PENYUSUNAN CP MERUPAKAN BAGIAN DARI EVALUASI DAN PENGEMBANGAN KURIKULUM.

\section{SNPT}

Standar kompetensi lulusan merupakan kriteria minima1 tentang kualifikasi kemampuan lulusan yang mencakup sikap, pengetahuan, dan keterampilan yang dinyatakan dalam rumusan capaian pembelajaran lulusan.

Rumusan capaian pembelajaran 1ulusan sebagaimana dimaksud pada ayat (1) wajib:

mengacu pada deskripsi capaian pembelajaran lulusan KKNI; dan

memiliki kesetaraan dengan jenjang kualifikasi pada KKNI.
DESKRIPSI UMUM (SIKAP \& TATA NILAI)

a. Bertaqwa kepada Tuhan Yang Maha Esa.

b. Memiliki moral, etika dan kepribadian yang baik di dalam menyelesaikan tugasnya.

c. Berperan sebagai warga negara yang bangga dan cinta tanah air serta mendukung perdamaian dunia.

d. Mampu bekerja sama dan memiliki kepekaan sosial dan kepedulian yang tinggi terhadap masyarakat dan lingkungannya.

e. Menghargai keanekaragaman budaya, pandangan, kepercayaan, dan agama serta pendapat/temuan original orang lain.

f. Menjunjung tinggi penegakan hukum serta memiliki semangat untuk mendahulukan kepentingan bangsa serta masyarakat luas. 


\section{KETRAMPILAN UMUM LULUSAN PROGRAM PROFESI}

- mampu bekerja di bidang keahlian pokok untuk jenis pekerjaan yang spesifik, dan memiliki kompetensi kerja yang minima setara dengan standar kompetensi kerja profesinya;

- mampu membuat keputusan yang independen dalam menjalankan pekerjaan profesinya berdasarkan pemikiran logis, kritis, sistematis, dan kreatif;

- mampu menyusun laporan atau kertas kerja atau menghasilkan karya desain di bidang keahliannya berdasarkan kaidah rancangan dan prosedur baku, serta kode etik profesinya, yang dapat diakses oleh masyarakat akademik;

- mampu mengomunikasikan pemikiran/argumen atau karya inovasi yang bermanfaat bagi pengembangan profesi, dan kewirausahaan, yang dapat dipertanggungiawabkan secara ilmiah dan etika profesi, kepada masyarakat terutama masyarakat profesinya;

- mampu melakukan evaluasi secara kritis terhadap hasil kerja dan keputusan yang dibuat dalam melaksanakan pekerjaannya oleh dirinya sendiri dan oleh sejawat

- mampu meningkatkan keahlian keprofesiannya pada bidang yang khusus melalui pelatihan dan pengalaman kerja;

- mampu meningkatkan mutu sumber daya untuk pengembangan program strategis organisasi;

- mampu memimpin suatu tim kerja untuk memecahkan masalah pada bidang profesinya;

- mampu bekerja sama dengan profesi lain yang sebidang dalam menyelesaikan masalah pekerjaan bidang profesinya;

- mampu mengembangkan dan memelihara jaringan kerja dengan masyarakat profesi dan kliennya;

- bertanggungjawab atas pekerjaan di bidang profesinya sesuai dengan kode etik profesinya;

- mampu meningkatkan kapasitas pembelajaran secara mandiri.

- Mampu berkontribusi dalam evaluasi atau pengembangan kebijakan nasional dalam rangka peningkatan mutu pendidikan profesi atau pengembangan kebijakan nasional pada bidang profesinya;

mampu mendokumentasikan, menyimpan, mengaudit, mengamankan, dan menemukan kembali data dan informasi untuk keperluan pengembangan hasil kerja profesinya;

\section{KETRAMPILAN KHUSUS}

Dalam menyusun "keterampilan khusus", penyusun wajib melakukan analisis terhadap:

- masukan tentang kompetensi terpakai yang dapat diperoleh dari alumni yang bekerja 1-3 tahun setelah lulus pada institusi nasional dan internasional,

- usulan kompetensi kerja yang dibutuhkan oleh berbagai pemangku kepentingan (pemerintah, badan hukum penyelengara, perguruan tinggi penyelenggara, asosiasi profesi/keahlian, kolegium/konsorsium keilmuan),

- kompetensi kerja yang relevan yang telah ditetapkan oleh badan sertifikasi yang relevan baik pada tingkat nasional maupun internasional,

- rumusan CP lulusan program studi sejenis yang memiliki reputasi baik di dalam dan luar negeri,

- standar akreditasi baik dari dalam maupun luar negeri,

- dan dari sumber lain yang pernah ditulis, misalnya dari jurnal pendidikan.

- probabililtas bergesernya kompetensi kerja pada jangka pendek dan menengah 


\section{STANDAR NASIONAL PENDIDIKAN TINGGI}

Standar Nasional Pendidikan Tinggi, adalah satuan standar yang meliputi Standar Nasional Pendidikan, ditambah dengan Standar Nasional Penelitian, dan Standar Nasional Pengabdian kepada Masyarakat.

- Standar Nasional Pendidikan, adalah kriteria minimal tentang pembelajaran pada jenjang pendidikan tinggi di perguruan tinggi di seluruh wilayah hukum Negara Kesatuan Republik Indonesia.

- Standar Nasional Penelitian adalah kriteria minimal tentang sistem penelitian pada perguruan tinggi yang berlaku di seluruh wilayah hukum Negara Kesatuan Republik Indonesia.

- Standar Nasional Pengabdian kepada Masyarakat adalah kriteria minimal tentang sistem pengabdian kepada masyarakat pada perguruan tinggi yang berlaku di seluruh wilayah hukum Negara Kesatuan Republik Indonesia.

\section{TUJUAN STANDAR NASIONAL PENDIDIKAN TINGGI}

- menjamin tercapainya tujuan pendidikan tinggi yang berperan strategis dalam mencerdaskan kehidupan bangsa, memajukan ilmu pengetahuan dan teknologi dengan menerapkan nilai humaniora serta pembudayaan dan pemberdayaan bangsa Indonesia yang berkelanjutan;

- menjamin agar pembelajaran pada program studi, penelitian, dan pengabdian kepada masyarakat yang diselenggarakan oleh perguruan tinggi di seluruh wilayah hukum Negara Kesatuan Republik Indonesia mencapai mutu sesuai dengan kriteria yang ditetapkan dalam Standar Nasional Pendidikan Tinggi; dan

- mendorong agar perguruan tinggi di seluruh wilayah hukum Negara Kesatuan Republik Indonesia mencapai mutu pembelajaran, penelitian, dan pengabdian kepada masyarakat melampaui kriteria yang ditetapkan dalam Standar Nasional Pendidikan Tinggi secara berkelanjutan 


\section{STANDAR NASIONAL PENDIDIKAN TINGGI}

\section{Standar Nasional Pendidikan Tinggi wajib}

- dipenuhi oleh setiap perguruan tinggi untuk mewujudkan tujuan pendidikan nasional;

- dijadikan dasar untuk pemberian izin pendirian perguruan tinggi dan izin pembukaan program studi;

- dijadikan dasar penyelenggaraan pembelajaran berdasarkan kurikulum pada program studi;

- dijadikan dasar penyelenggaraan penelitian dan pengabdian kepada masyarakat;

- dijadikan dasar pengembangan dan penyelenggaraan sistem penjaminan mutu internal;

- dijadikan dasar penetapan kriteria sistem penjaminan mutu eksternal melalui akreditasi.

\section{LAMA BELAJAR DAN BEBAN BELAJAR PER PROGRAM}

\section{SARJANA DAN PROFESI}

- paling lama 7 (tujuh) tahun akademik untuk program sarjana, program diploma empat/sarjana terapan, dengan beban belajar mahasiswa paling sedikit 144 (seratus empat puluh empat) sks;

- paling lama 3 (tiga) tahun akademik untuk program profesi setelah menyelesaikan program sarjana, atau program diploma empat/sarjana terapan, dengan beban belajar mahasiswa paling sedikit 24 (dua puluh empat) sks;

\section{MAGISTER DAN DOKTOR}

- paling lama 4 (empat) tahun akademik untuk program magister, program magister terapan, atau program spesialis, setelah menyelesaikan program sarjana, atau diploma empat/sarjana terapan, dengan beban belajar mahasiswa paling sedikit 36 (tiga puluh enam) sks;

- paling lama 7 (tujuh) tahun akademik untuk program doktor, program doktor terapan, atau program subspesialis, setelah menyelesaikan program magister, program magister terapan, atau program spesialis, dengan beban belajar mahasiswa paling sedikit 42 (empat puluh dua) sks. 


\section{PROGRAM PENDIDIKAN PROFESI}

PROGRAM PROFESI SEBAGAIMANA DIMAKSUD PADA AYAT

(1) HURUF E DISELENGGARAKAN SEBAGAI PROGRAM

LANIUTAN YANG TERPISAH ATAU TIDAK TERPISAH DARI

PROGRAM SARJANA, ATAU PROGRAM DIPLOMA

EMPAT/SARJANA TERAPAN.

\section{BEBAN BELAJAR PER SKS}

responsi, atau tutorial, terdiri atas:

- kegiatan tatap muka 50 (lima puluh) menit per

minggu per semester;

- kegiatan penugasan terstruktur 60 (enam puluh) menit per minggu per semester; dan

- kegiatan mandiri 60 (enam puluh) menit per minggu per semester.

- 1 (satu) sks pada proses pembelajaran berupa seminar atau bentuk lain yang sejenis, terdiri atas:

- kegiatan tatap muka 100 (seratus) menit per minggu per semester; dan

- kegiatan mandiri 70 (tujuh puluh) menit per

minggu per semester

- 1 (satu) sks pada proses pembelajaran berupa

Bentuk pembelajaran dapat berupa:

- kuliah/Tatap Muka;

- responsi dan tutorial; seminar; dan

- praktikum, praktik studio, praktik

bengkel, atau praktik lapangan

praktikum, praktik studio, praktik bengkel, praktik

lapangan, penelitian, pengabdian kepada masyarakat, dan/atau proses pembelajaran lain yang sejenis, 170 (seratus tujuh puluh) menit per minggu per semester. 


\section{RENCANA PEMBELAJARAN SEMESTER}

- Perencanaan proses pembelajaran sebagaimana disusun untuk setiap mata kuliah dan disajikan dalam rencana pembelajaran semester (RPS) atau istilah lain
- Rencana pembelajaran semester (RPS) atau istilah lain ditetapkan dan dikembangkan oleh dosen secara mandiri atau bersama dalam kelompok keahlian suatu bidang ilmu pengetahuan dan/atau teknologi dalam program studi

\section{KOMPONEN MINIMAL RENCANA PEMBEAJARAN SEMESTER}

- Nama Universitas

- Nama Fakultas

- Nama program studi,

- Nama dan kode mata kuliah.

- Semester, sks,

- Nama dosen pengampu;

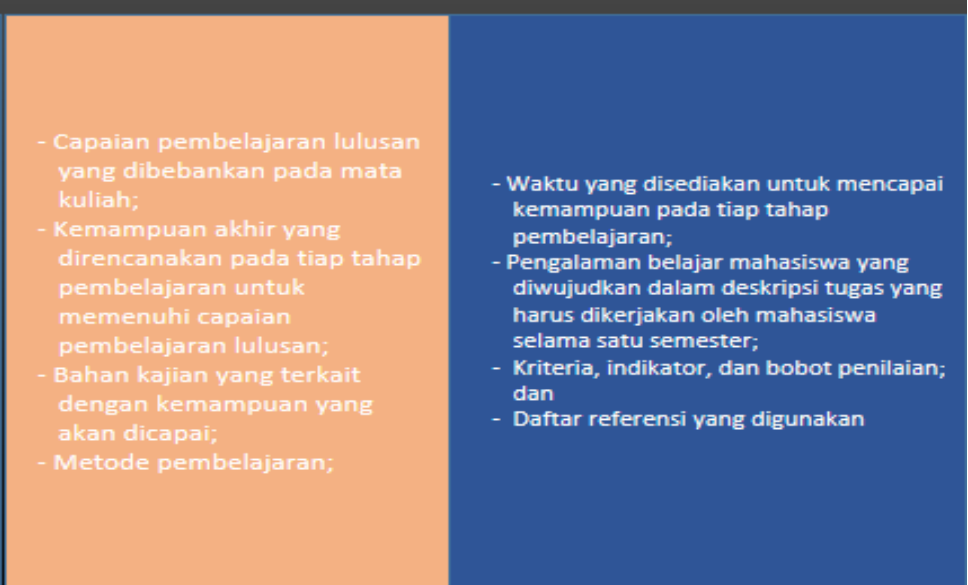




\section{PENILAIAN PRESTASI BELAJAR}

Prinsip penilaian mencakup prinsip

edukatif, otentik, objektif, akuntabel, dan

KUALIFIKASI KEBERHASILAN MAHASISWA DALAM

tansparan vang dilakulkan secars

MENEMPUH SUATU MATA KULIAH

Teknik penilaian terdiri atas

observasi, partisipasi, unjuk kerja,

tes tertulis, tes lisan, dan angket.

Mahasiswa berprestasi akademik tinggi

merupakan mahasiswa yang

mempunyai indeks prestasi semester

(IPS) lebih besar dari 3,00 (tiga koma

nol nol) dan memenuhi etika akademik.

huruf A setara dengan angka 4 (empat)

berkategori sangat baik;

huruf $B$ setara dengan angka 3 (tiga) berkategori baik;

huruf C setara dengan angka 2 (dua) berkategori cukup;

huruf D setara dengan angka 1 (satu) berkategori kurang; atau

e. huruf $E$ setara dengan angka $O$ (nol) berkategori sangat kurang

\section{MASTERS DAN PH.D DALAM PENDIDIKAN SEJARAH}
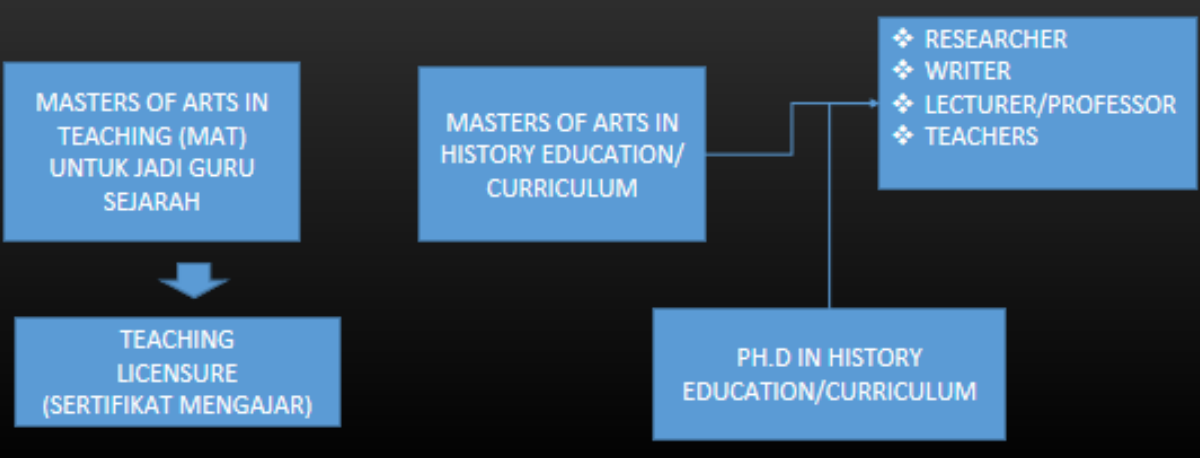

46 | Seminar Nasional Sejarah ke 4 Jurusan Pendidikan Sejarah Universitas Negeri Padang 


\section{MASTERS OF ARTS IN TEACHING (HISTORY EDUCATION)}

\section{MAT BOSTON UNIVERSITY}

\section{EDUCATION CORE COURSES (12 CR)}

- SED ED 502/503 Professional Teaching Seminar: Analyzing Foundations of Teaching $(2 \mathrm{cr}$ )

- SED DS 502 Introduction to Adolescent Development $(2 \mathrm{cr})$

- SED SE 510 Special Education: Curriculum and Instruction $(2 \mathrm{cr}$ )

- SED CT 534 A Practical Approach to Classroom Management ( $2 \mathrm{cr}$ )

- SED TL 525 Teaching English Learners in the Middle/High School (4 cr)
SOCIAL STUDIES COURSES (2OCR)

- SED SO 572 Curriculum and Special Methods for History and Social Science, 5-12 (4 cr)

- SED SO 566 Developing Historical Literacy, 5-12 (4 cr)

- SED SO 567 History Laboratory (2 cr)

- SED SO 520 Project Citizen: Promoting Civic Engagement ( $2 \mathrm{cr}$ )

- Two social studies content-based electives at the Graduate School of Arts \& Sciences $(8 \mathrm{cr})$ 


\section{Course Details Total Hours: 46}

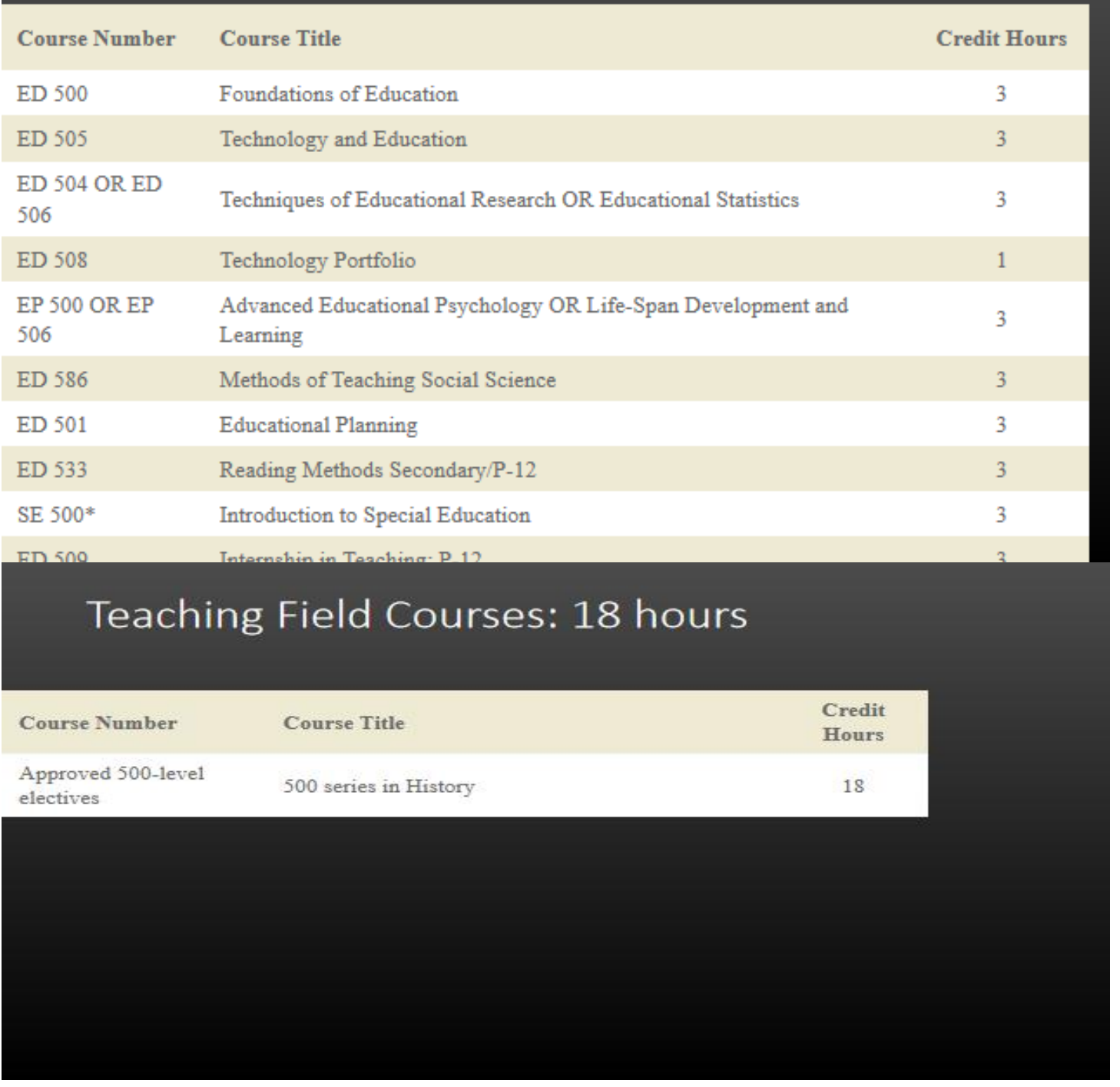




\section{CONNECTICUT UNIVERSITY-MAT PROGRAM}

All MAT programs include core, specialization, and capstone components

Core

MAT 510 Research on Teaching Diverse Learners

MAT 511 Introduction to Special Education 1

MAT 520 Design and Delivery of Instruction 4

MAI 530 Meeting the Needs of Special Learners in the Classroom 2

MAT 531 Literacy and Language Issues in the Classroom 3

ING 521 Meeting the Needs of ELLs in the Classroom 1

MAT 534 Creating Productive Learning Environments 3

MAT 541 Internship Seminar 3

MAT 551 Perspectives on Educational Policy and Practice 3

- Specialization

MaT 510 High Leverage Content in the Discipline (HISTORY)

3

MAT 529 Content Pedagogy in Certification Area I

MAT 539 Content Pedagogy in the Certification Area II

MAT 533 Field Experience in the Certification Area: English,

History/Social Studies, Mathematics, Modern

Language, Science, and Special Education

MAT 540 Internship in the Certification Area: English, History/

Social Studies, Mathematics, Modern Language,

Science, and Special Edueation. 


\section{MASTERS OF ARTS IN HISTORY EDUCATION (CURRICULUM)}

\section{UCL Institute of Education}

Compulsory modules

- What is Education?

- Effective Learning in History

- Understanding Research

- Dissertation with Integrated Research Methods (IRM) OR Report with Integrated Research Methods (IRM)

\section{Optional modules}

- Education and Identities: Citizenship, Rights, Narratives

- Holocaust in the Curriculum

- Teaching Controversial Issues

- Debates in the History of Education

- Issues and Debates in RE

- Comparative Education: Theories and Methods

- Contemporary Issues in English Education

- Critical Perspectives on Learning and Teaching

- Curriculum Policy and Practice

- Development Education in the Era of Globalisation 


\section{$\mathrm{UCL}$}

\section{Optional modules}

- Leading the Geography Curriculum

- Global citizenship Education: Research, Policy and Practice

- Education and Muslim communities

- Education, Ethics and Imagination in a Globalising World

- Gender, Education and Development

- Philosophy of Education: Knowledge, Mind and

- Philosophy of Education: Values, Aims and Society

- Assessment: Issues and Practice

- Minorities, Migrants and Refugees in National Education Systems

- Sociology of Education

PH.D IN HISTORY EDUCATION

51 | Seminar Nasional Sejarah ke 4 Jurusan Pendidikan Sejarah Universitas Negeri Padang 


\section{STANFORD UNIVERSITY}

Ph.D. Program

\section{Overview \& Description}

The program in History Education is concerned with how young people make sense of the past in schoo and outteaching and learning and, most broadly, engages the very nalure of historical consciousness. What does it history taught and learned in and out of schools? How

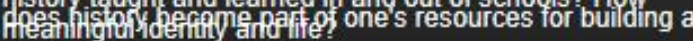

There are no formal prerequisites for admission to our Ph.D. program. Experience in teaching history is a definite asset and provides a useful entry point to many of these questions. But more important than any particular prior experience is a boundless curiosity to understand how the past shapes understanding in the present and how we can learn more about designing effective programs. Many backgrounds prepare one for successful graduate study: teaching, filmmaking, museum or web design, tour guiding, and archival work are some of the many possibilities

Taught well history fosters tolerance for complexity and young people to dscem reasoned interpretations from judgment? What can edycators do to cultivate reasoning just names and dates? State-of-the-art research shows that even elementary school children can learn to thin historically but such classrooms are rare. How can we

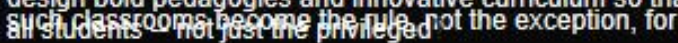

Sample Ph.D. Courses

\section{EDUC 325A: Proseminar 1}

Instructors:

Reguired of and limited to first-year Education doctoral students. Core questions in education: What is taught, to whom, and why how do people learn; how do teachers

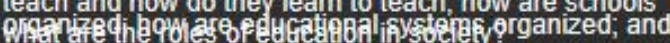

\section{EDUC 325B: Proseminar 2}

\section{Instructors:}

$\&$

Required of and limited to first-year Education doctoral students. Core questions in equcation: what is taught, to whom, and why how do people eam, how do teachers

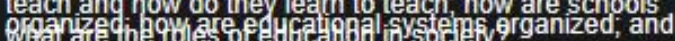

EDUC 325C: Proseminar 3

Instructors: Anthony Antonio \& Prudence Carter

Reguired of and limited to first-year Education doctoral

whom, and why how do people leam; how do teachers

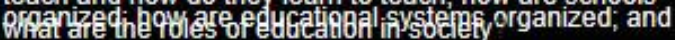

EDUC 356/HISTORY 337C : Memory, Instructor: I

The program in History Education is concerneg with how of-school settings. The program explores core issues of very nature of historical consciousness. What does it nean to in a present suinused by perfflfy and ifit?

\section{EDUC 395: Scholarly. Writing in Education Instructor: Sam Wineburg}

Focus is on producing articles for scholarly journals in education and the social sciences. Ethics and craft of scholarty publishing. Writing opinion articles for lay audiences on issues of educational and social import 
- Teaching for Historical Thinking: Teacher Conceptions, Practices, and Constraints, by Daisy Martin - Learning Our Histories: History and Identity at a Jewish Community High School, by Sivan Zakai

- Excellence for All Amencen School Retom. 1985-20.08, by Jack Schneider

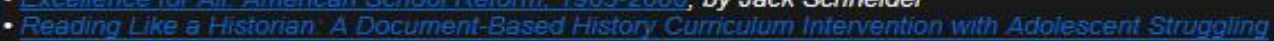

Reaviers, by Abby Reisman

- What Ever Student Should know and Be Able To Do". The Meking of California's Framework, Standarols

and Tests for Histon-Social Science, by Brad Fogo

\section{EDUC 201/HISTORY 158B; History of}

Instructor:

How education came to its current forms and functions, from the colonial experience to the present. Focus is on

the 19 in-century invention of the common school system. 20th-century emergence of progressive education reform and the developmenis since $W W$. The role of gender and race, the development of the high school and tereringy, and school organization, curriculum, and

\section{EDUC 265/HISTORY 158C: History of}

Instructor: Leah Gardort

Major periods of evolution, particularly since the mid-19th century. Premise: insights into contemporary higher education can be obtained through its antecedents, particularly regarding issues of governance, mission, access, curriculum, and the changing organization of colleges and universities

\section{EDUC 220D/HISTORY 258E:History of chool Retom: Orions, Policies, Instructor:}

Focus is on 20th-century U.S. intended and unintended patterns in school change; the paradox of reform that schools are often reforming but never seem to change much; rhetorics of reform and factors that inhibit change. Case studies emphasize the American

\section{EDUC 253X/HISTORY 237B: Teaching

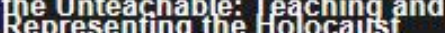

Theodore Adorno asked whether it was possible to Write poetry after Auschwiz; whatever the answer, each year witnesses exponential growth in state-sponsored

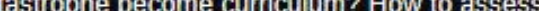
What students leam from these eirorts. The Nazis eftorts to teach for hate, and contemporary parallels. ristorical and educational sources, especlally films and 
EDUC 373X: Teaching in the Humanitiesinstructors:

Relatively little attention has been paid to the role of

humanities courses in teaching both general and disciplinary skills in reading and writing. With the growth of small schools,

more middle and high school teachers find themselves

teaching Humanities courses. This seminar will explore what it

means to teach the humanities, with special attention to how

such courses can develop disciplinary reading and writing skills

Course will investigate how we develop tools to assess

teaching and learning in the humanities

\section{EDUC 290C: Introduction to Statistical}

Instructor: Dan Schureti

Describing measured, count, and categorical data.

Statistical inference procedures for comparisons of group

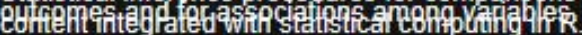

\section{EDUC 250C: Quantative Analysis \\ Instructors: \\ $\&$}

Primarily for doctoral students; part of doctoral research core; prerequisite for advanced statistical methods courses in School of Education. Basic regression, a widely used data-analytic procedure, including multiple and curvilinear regression, regression diagnostics, analysis of residuals and model selection,

logistic regression. Proficiency with statistical computer packages

\section{EDUC 250B: Statistical Analysis in} Instructor: Elic Baltinger

Primarily for doctoral students; part of doctoral research core, preregusite or advanced sato methods courses in schpol of Education. Basic regression, a and curvilinear regression, regressjon diagnostics, and feresesipn. Proficiency with statistical computer
EDUC 318X: The Riscourses of Teaching Instructor:

Students examine language social relationships, and conceptions of reading comprenension and their it means focompenend text how class oon discourse matters ungerstandings purposes and reations ips should

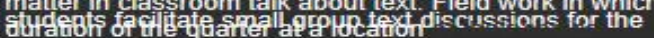

\section{EQUC 424: Introguction to Research in} Instructor:

Limited to second-year doctoral students in CTE. How to conceptualize, design, and interpret research. How to read, interpret, and critique research; formulate

meaningful research questions; evaluate and conduct a literature review; and conceptualize a study. Readings include studies from different research paradigms. Required literature review in an area students expect to explore for their qualifying paper
EDUC 466: Doctoral Seminar in Curriculum Instructor:

Required of all doctoral students in CTE, normally during their second year in the program. Students present their ideas regarding a dissertattor or other research project, and prepare a short research proposal that often satisfies their second-year review. (CTE) 


\section{NIIT: MAT HISTORY EDUCATION Foundations Courses}

- Social Foundations of Urban Schools 26:300:500 (3)

- Adolescent Psychology and the Urban Experience 26:300:501 (3)

- The Urban Teacher Education Department requires one course studying a culture represented by the urban schoolchildren of New Jersey. Many different courses fulfill this requirement. Please see the student advisor if you have any questions.

- After admission to the Urban Teacher Education Program, you will pursue Secondary Certification.

- Courses for Secondary Certification:

- 26:300:500 Social Foundations of Urban Schools

- Issues in Urban Education 21:300-540 (3)

- Information and Communication Technologies in Secondary Schools 21:300:410 (3)

fall semester.

- Methods of Teaching Secondary School 21:300:386 (3)

- Curriculum and Instruction in Secondary Classrooms 21:300:388 (3)
Note: The above courses should be taken together during spring semester.

- One semester prior to student teaching*+* you must enroll in the Secondary Practicum 21:300:414/418 (3). Requires $50-60$ hours in a NPS (Newark Public School) classroom. You will be placed with a Cooperating
Mentor for this experience.

All sturents are required to

- All students are required to complete Student Teaching and Seminar 21:300;487 (6). You will be placed with a NPS Cooperating Teacher for your student teaching experience. You may NoT take any other courses while you are student teaching. However if you need to keep your status as a full-time student, you may enroll in one or both of the Supervised Teaching courses 21:300:427/428 (3).

55 | Seminar Nasional Sejarah ke 4 Jurusan Pendidikan Sejarah Universitas Negeri Padang 


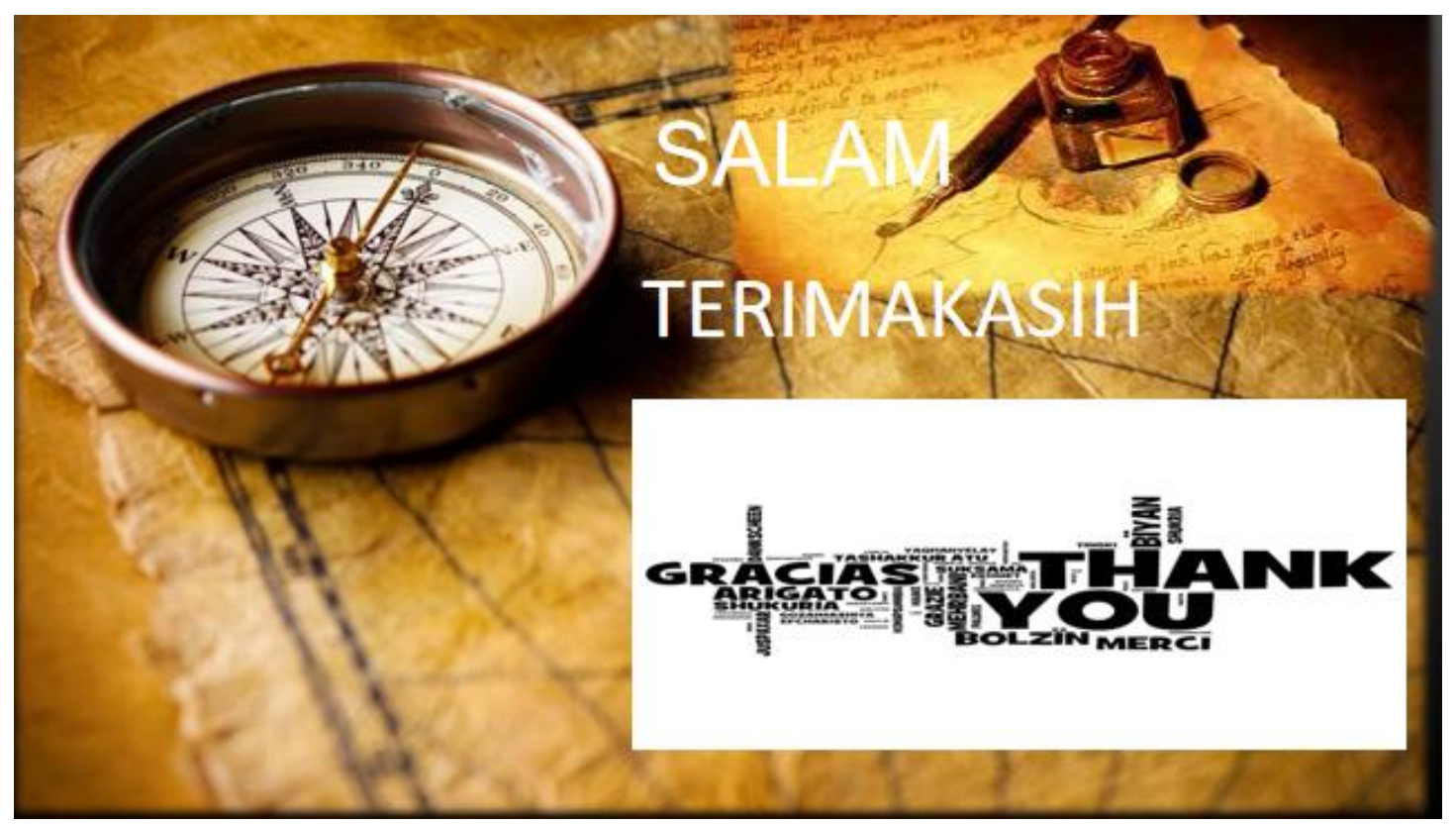

